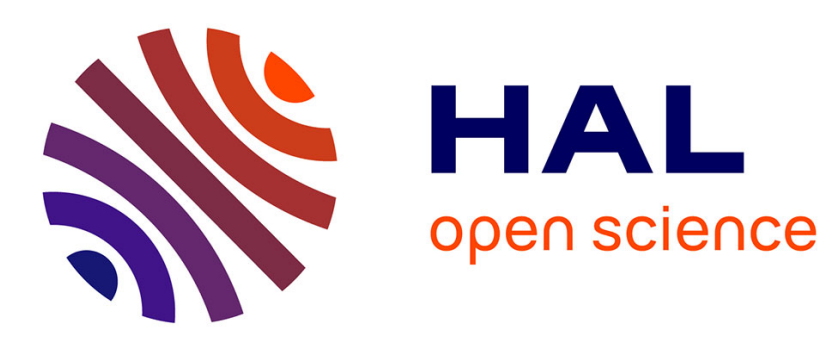

\title{
Fighting Sarcopenia in Older Frail Subjects: Protein Fuel for Strength, Exercise for Mass \\ Yves Y. Boirie
}

\section{To cite this version:}

Yves Y. Boirie. Fighting Sarcopenia in Older Frail Subjects: Protein Fuel for Strength, Exercise for Mass. Journal of the American Veterinary Medical Association, 2013, 14 (2), pp.140-143. 10.1016/j.jamda.2012.10.017 . hal-00939846

\section{HAL Id: hal-00939846 https://hal.science/hal-00939846}

Submitted on 28 May 2020

HAL is a multi-disciplinary open access archive for the deposit and dissemination of scientific research documents, whether they are published or not. The documents may come from teaching and research institutions in France or abroad, or from public or private research centers.
L'archive ouverte pluridisciplinaire HAL, est destinée au dépôt et à la diffusion de documents scientifiques de niveau recherche, publiés ou non, émanant des établissements d'enseignement et de recherche français ou étrangers, des laboratoires publics ou privés. 


\section{(2)}

4

\section{Fighting Sarcopenia in Older Frail Subjects: Protein Fuel for Strength, Exercise} for Mass

\section{To the Editor:}

Skeletal muscle has a global impact on our health not only because it permits us to stand or to move but also because of its numerous metabolic activities, including its capacities to produce energy from the mitochondrial oxidation of substrate or to deliver amino acids to the body in case of higher needs. Muscle mass loss together with alterations of muscle function, also defined as sarcopenia, ${ }^{1,2}$ is an important part of the frailty syndrome leading to disability, dependence, and increased mortality in the older subjects. Sarcopenia occurs not only with aging; chronic diseases are associated with loss of muscle mass and function too. Therefore, it is of major interest to understand how targeted therapeutic interventions, especially through food intake and physical exercise, are able to promote muscle mass and function in older persons through their specific impact on the regulation of muscle protein metabolism. ${ }^{3,4}$

Dietary protein ingestion and the subsequent changes in plasma amino acid and hormones like insulin are key regulating signals promoting muscle protein anabolism through the induction of muscle translation initiation pathways., ${ }^{5,6}$ Interestingly, these intracellular signals may be also modulated by other stimulating events such as mechanical fiber contraction to promote muscle protein synthesis. ${ }^{6}$ During aging, a blunted response of muscle protein synthesis to nutrient intake has been reported to be one of the greatest limitations to muscle preservation by several investigators, 4,5,7,8 suggesting an "anabolic resistance," which may also be found in many other circumstances such as in patients with chronic obstructive pulmonary disease, with kidney disease, or in the intensive care unit. ${ }^{9-13}$ According to age-related anabolic resistance that may be induced by inflammation, ${ }^{14}$ insulin resistance, ${ }^{15-18}$ and more recently by lipotoxicity, ${ }^{19,20}$ the postprandial levels of plasma amino acids are crucial to reach the threshold triggering intracellular translation initiation pathways toward protein synthesis as depicted in Figure 1. This is the reason why muscle synthetic response to dietary protein or to essential amino acids has been initially reported to be preserved when adequate or high amounts of dietary proteins or amino acids were administered. ${ }^{21-24}$ However, when smaller intakes of essential amino acids were ingested, even though appropriate with regard to recommended dietary allowance, response of muscle protein synthesis was reduced. ${ }^{25}$ Therefore, during frailty or age-related chronic diseases, postprandial stimulation of muscle protein synthesis may be restored by increasing either the anabolic stimuli (amino acids availability, hormonal responses) or the sensitivity to them (potential role of physical activity) as schematically proposed in Figure 2. Hence, providing higher amounts of dietary proteins to frail resistant older persons together with physical activity as a "multimodal therapeutical approach" seems to be an appropriate strategy to optimize muscle anabolic response and ultimately promote gain in muscle mass and function. However, most of the studies have addressed this question in healthy older subjects not always characterized as subjects with sarcopenia, and very few have been performed on frail people. Moreover, it is of major concern to obtain simultaneous data on muscle mass and function from well designed long-term intervention trials.

Some recent studies have addressed these questions in frail subjects with sarcopenia, ${ }^{26-28}$ malnourished or hospitalized, ${ }^{29}$ using various nutritional strategies (essential amino acids or dietary proteins supplementation) alone or together with physical exercise. The 2 recent randomized, double-blind, placebocontrolled studies from Tieland et al. ${ }^{27,28}$ The Journal of American Medical Directors Association determined the impact of 24 weeks of protein supplementation providing twice daily $15 \mathrm{~g}$ over 24 weeks alone ${ }^{28}$ or in combination to resistance training ${ }^{27}$ on muscle mass, strength, and physical performance in frail older adults. The protein supplement alone, consisting of protein supplementations at breakfast and lunch to spread out protein intakes throughout the 3 meals, did not increase muscle mass but promoted a significantly higher physical performance. In addition, efficiency of protein intake on muscle mass and function was amplified by resistance exercise, suggesting a synergistic impact of dietary protein and physical activity on muscle anabolism in this frail population. The results of these 2 important reports, which differ from others, raise many clinical and metabolic questions, especially regarding the requirement, the distribution, the timing, and the source of proteins together with the additive effect of different types of physical exercise.

First, at the clinical level, increasing protein intake over the recommended dietary allowance for elderly subjects $(0.8 \mathrm{~g} / \mathrm{kg} / \mathrm{d})$ in frail elderly persons to $1.3-1.4 \mathrm{~g} / \mathrm{kg} / \mathrm{d}$ was able to induce a significant improvement of muscle function: this means that current recommendations for protein only based on nitrogen balance studies may not be adequate when applied to elderly patients with chronic disease, implying that the recommendations should also be focused on specific functional outcomes (muscle performance, metabolic responses, immune functions, bone health, appetite regulation...). Then, because of an "age-related muscle anabolic resistance" in the case of frailty and/or hospitalized patients, 


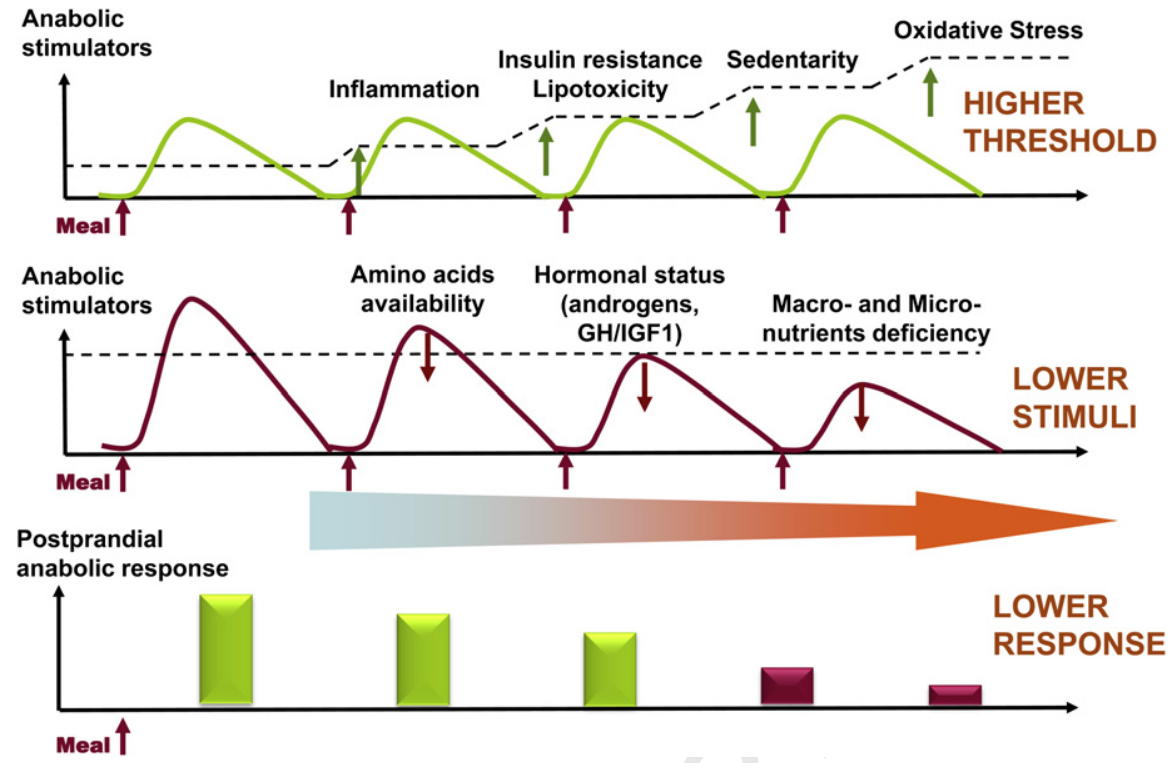

Fig. 1. Hypothetical temporal changes of postprandial muscle anabolism in response to meal intake: reaching the threshold is the goal!

providing more protein or essential amino acids in the diet and overcoming anabolic resistance by higher amino acid availability may improve postprandial muscle protein turnover and ultimately affect the quality of muscle proteins, which are exposed to oxidative stress attributable to their slow turnover. ${ }^{30}$ Different results between studies may also be explained by the time of metabolic assessment after the start of intervention. The early postprandial stimulation of muscle protein synthesis induced by a higher protein intake may be later counteracted by an increased protein breakdown in the postabsorptive state. This remark means that interpretation of data from interventional studies should consider the duration of exposure to nutritional administrations. We may hypothesize that differences between 2 nutritional trials after 10-15 days may disappear after 3 or 6 months, suggesting that short studies, which help to understand some of the metabolic responses at the muscle level, should also be completed by longterm studies with clinical outcomes.

As previously discussed and beyond protein quantity, modifying the dietary protein distribution across the daily meals to optimize postprandial muscle protein gain is another nutritional strategy. Previous results from our group in healthy elderly women suggested that a "pulse feeding" pattern in which $80 \%$ of dietary protein was administered in 1 single meal (ie, lunch) (with equal

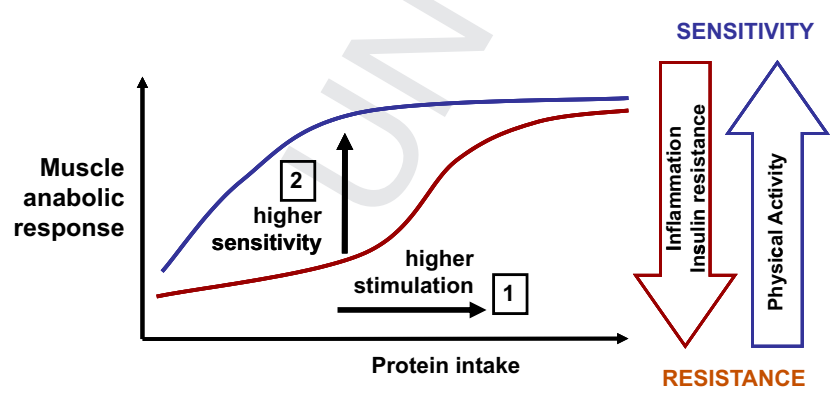

Fig. 2. Schematic representation of muscle anabolic response according to protein intake and exercise in older subjects. In situation of frailty, a lower muscle response may be restored by improving quantitative or qualitative aspects of protein consumption (box 1). Physical activity may potentiate the sensitivity of muscle protein synthesis to dietary protein (box 2). energy intake in all meals) was able to retain more nitrogen after 15 days than a spread diet. ${ }^{31}$ This concept was originally developed in a transition state of protein intake from 0.74 g.kg body $\mathrm{wt}^{-1} \cdot \mathrm{d}^{-1}$ during the adaptive period to 1.05 g.kg body $\mathrm{wt}^{-1} \cdot \mathrm{d}^{-1}$ in the experimental period. ${ }^{31}$ In the recent interventional studies performed in frail older subjects, protein distribution was rather close to a "spread diet" with equal amount across the day, because protein supplementation consisted mostly in $15 \mathrm{~g}$ protein enrichment at breakfast and at lunch, but not at dinner to reach about $30 \mathrm{~g}$ protein for all meals per day (ie, $1.4 \mathrm{~g} / \mathrm{kg} / \mathrm{d}$ throughout the study period). Thus, because of the high daily protein intake, it is likely that the "timing effect" of daily protein distribution was less contributive in these investigations. However, this question is still a matter of debate because a recent randomized controlled trial indicates that malnourished and at-risk hospitalized elderly patients could benefit from the "pulse protein feeding pattern" on lean mass for 6 weeks with a target of $1.31 \mathrm{~g}$ protein $/ \mathrm{kg} / \mathrm{d}^{29}$

To improve postprandial muscle synthesis using dietary proteins, not only the timing but also the quality and the speed of digestion of dietary proteins are other important new options. Indeed, dietary protein amino acid composition, particularly when highly rich in essential and branched chain amino acids, has to be considered, because branched chain amino acids are specific signals to activate mTOR pathway ${ }^{32-34}$ After their ingestion, these amino $\mathbf{Q}^{3}$ acids have to cross the splanchnic tissues which normally extract more than half of the dietary amino acids at first pass to be delivered up to the peripheral body tissues, especially the skeletal muscles. Because splanchnic extraction of amino acids was higher during healthy aging ${ }^{35,36}$ and even higher in the case of systemic inflammation for the production of acute phase proteins, a fast and ample elevation of plasma amino acid may be required to ultimately stimulate muscle protein synthesis. For this reason, the "fast/slow" protein concept initially developed at the whole body level ${ }^{37-39}$ has been applied in healthy aging to promote postprandial muscle protein synthesis. ${ }^{40-45}$ These studies confirmed that postprandial muscle protein accretion was improved by soluble milk protein (ie, whey protein ingestion in association with resistance exercise). ${ }^{42-45}$ From these studies, synergistic approaches are mostly required to improve muscle mass and function, but the amount, the type of protein, and the timing are 
crucial determinants to be considered in these new strategies. These nutritional concepts (protein feeding pattern, fast/slow protein, functional amino acids) and the timing together with exercise should now be tested on a practical and clinical basis in frail elderly subjects especially when protein intakes are limited. Finally, on top of nutrition and physical exercise, other strategies in future interventions focusing sarcopenia in frail older subjects could be also tested. Indeed anabolic hormones like androgens, ${ }^{46}$ drugs targeting mitochondrial metabolism, ${ }^{47}$ or pharmacologic enhancement of muscle perfusion during hyperinsulinemia ${ }^{18}$ are new potential tools to preserve muscle mass and function for a better quality of life during aging.

\section{References}

1. Rolland Y, Czerwinski S, Abellan Van Kan G, et al. Sarcopenia: Its assessment, etiology, pathogenesis, consequences and future perspectives. J Nutr Health Aging 2008;12:433-450.

2. Cruz-Jentoft AJ, Baeyens JP, Bauer JM, et al. Sarcopenia: European consensus on definition and diagnosis: Report of the European Working Group on Sarcopenia in Older People. Age Ageing 2010;39:412-423.

3. Walrand S, Boirie Y. Optimizing protein intake in aging. Curr Opin Clin Nutr Metab Care 2005;8:89-94.

4. Paddon-Jones D, Short KR, Campbell WW, et al. Role of dietary protein in the sarcopenia of aging. Am J Clin Nutr 2008;87:1562S-1566S

5. Walrand S, Guillet C, Salles J, et al. Physiopathological mechanism of sarcopenia. Clin Geriatr Med 2011;27:365-385.

6. Irving BA, Robinson MM, Nair KS. Age effect on myocellular remodeling: Response to exercise and nutrition in humans. Ageing Res Rev 2012;11: 374-389.

7. Attaix D, Mosoni L, Dardevet D, et al. Altered responses in skeletal muscle protein turnover during aging in anabolic and catabolic periods. Int J Biochem Cell Biol 2005;37:1962-1973.

8. Walker DK, Dickinson JM, Timmerman KL, et al. Exercise, amino acids, and aging in the control of human muscle protein synthesis. Med Sci Sports Exerc 2011;43:2249-2258.

9. Ferrando AA, Paddon-Jones D, Wolfe RR. Alterations in protein metabolism during space flight and inactivity. Nutrition 2002;18:837-841.

10. Mitch WE. Insights into the abnormalities of chronic renal disease attributed to malnutrition. J Am Soc Nephrol 2002;13:S22-S27.

11. Biolo G, Ciocchi B, Lebenstedt M, et al. Short-term bed rest impairs amino acidinduced protein anabolism in humans. J Physiol 2004;558:381-388.

12. Rennie MJ. Anabolic resistance in critically ill patients. Crit Care Med 2009;37: S398-S399.

13. Hommelberg PP, Langen RC, Schols AM, et al. Inflammatory signaling in skeletal muscle insulin resistance: Green signal for nutritional intervention? Curr Opin Clin Nutr Metab Care 2010;13:647-655.

14. Rieu I, Magne H, Savary-Auzeloux I, et al. Reduction of low grade inflammation restores blunting of postprandial muscle anabolism and limits sarcopenia in old rats. J Physiol 2009;587:5483-5492.

15. Boirie Y. Insulin regulation of mitochondrial proteins and oxidative phosphorylation in human muscle. Trends Endocrinol Metab 2003;14:393-394.

16. Guillet C, Boirie Y. Insulin resistance: A contributing factor to age-related muscle mass loss? Diabetes Metab 2005;31:5S20-25S26.

17. Rasmussen BB, Fujita $S$, Wolfe RR, et al. Insulin resistance of muscle protein metabolism in aging. FASEB J 2006;20:768-769.

18. Timmerman KL, Lee JL, Fujita S, et al. Pharmacological vasodilation improves insulin-stimulated muscle protein anabolism but not glucose utilization in older adults. Diabetes 2010;59:2764-2771.

19. Tardif N, Salles J, Landrier JF, et al. Oleate-enriched diet improves insulin sensitivity and restores muscle protein synthesis in old rats. Clin Nutr; 2011.

20. Masgrau A, Mishellany-Dutour A, Murakami H, et al. Time-course changes of muscle protein synthesis associated with obesity-induced lipotoxicity. J Physiol; 2012

21. Volpi E, Ferrando AA, Yeckel CW, et al. Exogenous amino acids stimulate net muscle protein synthesis in the elderly. J Clin Invest 1998;101:2000-2007.

22. Volpi E, Kobayashi H, Sheffield-Moore M, et al. Essential amino acids are primarily responsible for the amino acid stimulation of muscle protein anabolism in healthy elderly adults. Am J Clin Nutr 2003;78:250-258.

23. Paddon-Jones D, Sheffield-Moore M, Zhang XJ, et al. Amino acid ingestion improves muscle protein synthesis in the young and elderly. Am J Physiol Endocrinol Metab 2004;286:E321-E328.

24. Dillon EL, Sheffield-Moore M, Paddon-Jones D, et al. Amino acid supplementation increases lean body mass, basal muscle protein synthesis, and insulinlike growth factor-I expression in older women. J Clin Endocrinol Metab 2009;94:1630-1637.
25. Katsanos CS, Kobayashi H, Sheffield-Moore M, et al. Aging is associated with diminished accretion of muscle proteins after the ingestion of a small bolus of essential amino acids. Am J Clin Nutr 2005;82:1065-1073.

26. Kim HK, Suzuki T, Saito K, et al. Effects of exercise and amino acid supplementation on body composition and physical function in community-dwelling elderly Japanese sarcopenic women: A randomized controlled trial. J Am Geriatr Soc 2012;60:16-23.

27. Tieland M, Dirks ML, van der Zwaluw N, et al. Protein supplementation increases muscle mass gain during prolonged resistance-type exercise training in frail elderly people: A randomized, double-blind, placebo-controlled trial. J Am Med Dir Assoc 2012;13:713-719.

28. Tieland M, van de Rest O, Dirks ML, et al. Protein supplementation improves physical performance in frail elderly people: A randomized, double-blind, placebo-controlled trial. J Am Med Dir Assoc 2012;13:720-726.

29. Bouillanne O, Curis E, Hamon-Vilcot B, et al. Impact of protein pulse feeding on lean mass in malnourished and at-risk hospitalized elderly patients: A randomized controlled trial. Clin Nutr; 2012.

30. Murakami H, Guillet C, Tardif N, et al. Cumulative 3-nitrotyrosine in specific muscle proteins is associated with muscle loss during aging. Exp Gerontol 2012;47:129-135.

31. Arnal MA, Mosoni L, Boirie Y, et al. Protein pulse feeding improves protein retention in elderly women. Am J Clin Nutr 1999;69:1202-1208.

32. Dardevet D, Rieu I, Fafournoux P, et al. Leucine: A key amino acid in ageingassociated sarcopenia? Nutr Res Rev 2003;16:61-70.

33. Rieu I, Balage M, Sornet C, et al. Leucine supplementation improves muscle protein synthesis in elderly men independently of hyperaminoacidaemia. J Physiol 2006;575:305-315.

34. Casperson SL, Sheffield-Moore M, Hewlings SJ, et al. Leucine supplementation chronically improves muscle protein synthesis in older adults consuming the RDA for protein. Clin Nutr 2012;31:512-519.

35. Boirie Y, Gachon P, Beaufrere B. Splanchnic and whole-body leucine kinetics in young and elderly men. Am J Clin Nutr 1997;65:489-495.

36. Volpi E, Mittendorfer B, Wolf SE, et al. Oral amino acids stimulate muscle protein anabolism in the elderly despite higher first-pass splanchnic extraction. Am J Physiol 1999;277:E513-E520.

37. Boirie Y, Dangin M, Gachon P, et al. Slow and fast dietary proteins differently modulate postprandial protein accretion. Proc Natl Acad Sci U S A 1997;94: 14930-14935.

38. Dangin M, Boirie Y, Garcia-Rodenas C, et al. The digestion rate of protein is an independent regulating factor of postprandial protein retention. Am J Physiol Endocrinol Metab 2001;280:E340-E348.

39. Dangin M, Boirie Y, Guillet C, et al. Influence of the protein digestion rate on protein turnover in young and elderly subjects. J Nutr 2002;132: 3228S-3233S.

40. Koopman R, Crombach N, Gijsen AP, et al. Ingestion of a protein hydrolysate is accompanied by an accelerated in vivo digestion and absorption rate when compared with its intact protein. Am J Clin Nutr 2009;90:106-115.

41. Koopman $\mathrm{R}$, Walrand $\mathrm{S}$, Beelen $\mathrm{M}$, et al. Dietary protein digestion and absorption rates and the subsequent postprandial muscle protein synthetic response do not differ between young and elderly men. J Nutr 2009;139: 1707-1713.

42. Pennings B, Boirie Y, Senden JM, et al. Whey protein stimulates postprandial muscle protein accretion more effectively than do casein and casein hydrolysate in older men. Am J Clin Nutr 2011;93:997-1005.

43. Burd NA, Yang Y, Moore DR, et al. Greater stimulation of myofibrillar protein synthesis with ingestion of whey protein isolate v. micellar casein at rest and after resistance exercise in elderly men. Br J Nutr 2012;108:958-962.

44. Pennings B, Groen B, de Lange A, et al. Amino acid absorption and subsequent muscle protein accretion following graded intakes of whey protein in elderly men. Am J Physiol Endocrinol Metab 2012;302:E992-E999.

45. Yang Y, Breen L, Burd NA, et al. Resistance exercise enhances myofibrillar protein synthesis with graded intakes of whey protein in older men. Br J Nutr; 2012:1-9.

46. Horstman AM, Dillon EL, Urban RJ, Sheffield-Moore M. The role of androgens and estrogens on healthy aging and longevity. J Gerontol A Biol Sci Med Sci 2012;67:1140-1152.

47. Wenz T, Rossi SG, Rotundo RL, et al. Increased muscle PGC-1alpha expression protects from sarcopenia and metabolic disease during aging. Proc Natl Acad Sci U S A 2009;106:20405-20410.

Clermont Université, Université d'Auvergne, Unité dé Nutrition $\mathbf{Q s}$ Humaine, Clermont-Ferrand, France

INRA, UMR 1019, UNH, CRNH Auvergne, Clermont-Ferrand, France CHU Clermont-Ferrand, Service de Nutrition Clinique Clermont-Ferrand, France 


\section{AUTHOR QUERY FORM}

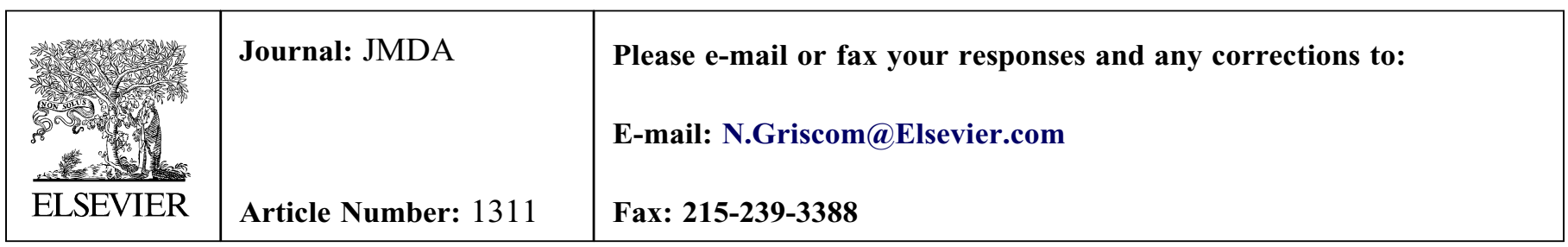

Dear Author,

Please check your proof carefully and mark all corrections at the appropriate place in the proof (e.g., by using on-screen annotation in the PDF file) or compile them in a separate list. Note: if you opt to annotate the file with software other than Adobe Reader then please also highlight the appropriate place in the PDF file. To ensure fast publication of your paper please return your corrections within 48 hours.

For correction or revision of any artwork, please consult http://www.elsevier.com/artworkinstructions.

Any queries or remarks that have arisen during the processing of your manuscript are listed below and highlighted by flags in the proof.

\begin{tabular}{|c|l|}
\hline $\begin{array}{c}\text { Location } \\
\text { in article }\end{array}$ & \multicolumn{1}{c|}{$\begin{array}{c}\text { Query / Remark: Click on the Q link to find the query's location in text } \\
\text { Please insert your reply or correction at the corresponding line in the proof }\end{array}$} \\
\hline Q1 & Please confirm that this is a Letter to the Editor. \\
Q2 & $\begin{array}{l}\text { Expanded RDA to recommended dietary allowance. Please confirm. } \\
\text { Q3 }\end{array}$ \\
Q4 & Rease use expanded form for mTOR (mammalian target of rapamycin?). \\
Q5 & Ref 20: Please provide volume and page numbers. \\
Q6 & Ref 30: Please provide volume and page numbers. \\
Q7 & Ref 45: Please provide volume number. \\
Q8 & Please confirm that given names and surnames have been identified correctly. \\
& \multicolumn{2}{|}{$\begin{array}{l}\text { Please check this box if you have no } \\
\text { corrections to make to the PDF file }\end{array}$} \\
\hline
\end{tabular}

Thank you for your assistance. 